\title{
Likuiditas dan Kebijakan Hutang Pengaruhnya terhadap Kinerja Perusahaan dan Dampaknya Terhadap Nilai Perusahaan pada Industri Sektor Telekomunikasi di Indonesia
}

\author{
Nardi Sunardi ${ }^{1}$; Fitria Febrianti ${ }^{2}$ \\ 1,2) Universitas Pamulang, dosen01030@unpam.ac.id
}

\section{ARTICLES \\ INFORMATION}

ABSTRACT

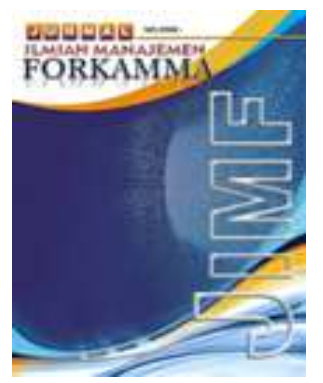

\section{JURNAL ILMIAH MANAJEMEN FORKAMMA}

\author{
Vol.3, No.3, Juli 2020 \\ Halaman : $269-282$ \\ (c) LPPM \& FORKAMMA
}

Prodi Magister Manajemen UNVERSITAS PAMULANG

ISSN (online) : 2599-171X ISSN (print) : :2598-9545

\section{Keyword :}

Likuiditas; Kebijakan Hutang;

Kinerja Perusahaan;Nilai

Perusahaan

JEL. classification :

C33, G21, G34, N25

Contact Author :

\section{PRODI}

MAGISTER MANAJEMEN \& FORKAMMA UNPAM

JL.Surya Kencana No.1 Pamulang

Tangerang Selatan - Banten

Telp. (021) 7412566, Fax (021) 7412491 Email :

jurnalforkamma.unpam@gmail.com
Penelitian ini bertujuan untuk menganalisis terjadinya pengaruh di nilai perusahaan. Informasi keuntungan perusahaan hingga harga sahamnya dengan nilai bukunya mencakup CR, DER, serta ROA, aplikasi bantuan antara lain Ms.Excel 2007 mencakup pembuatan tabel serta grafik, dan untuk analisis data memakai aplikasi Eviews 10.0. Hasil analisis data dari pengujian hipotesis secara parsial CR tidak mempengaruhi Kinerja Perusahaan, DER tidak-mempengaruhi Kinerja Perusahaan, CR mempengaruhi Nilai Perusahaan, DER tidak-mempengaruhi Nilai Perusahaan, Kinerja Perusahaan tidak-mempengaruhi Nilai Perusahaan. Secara bersama-sama CR dan DER mempengaruhi Kinerja Perusahaan, serta CR, DER dan ROA mempengaruhi Nilai Perusahaan. Dari analisis variabel intervening $\mathrm{CR}$, Kinerja Perusahaan terhadap Nilai Perusahaan, Kinerja Perusahaan secara statistik dan teoritis tak memediasi Likuiditas (CR) pada mempengaruhi Nilai Perusahaan (PBV). Serta untuk variabel intervening DER, Kinerja Perusahaan terhadap Nilai Perusahaan, Kinerja Perusahaan secara statistik dan teoritis tak memediasi taraf Kebijakan Hutang (DER) pada mempengaruhi Nilai Perusahaan (PBV).

The purpose of this observe is to research the effect that the enterprise has had on values. Profit information to a company stock price with the value of his book covering the $C R, D E R$ and ROA To process secondary data, researchers use software assistance software programs among whom Ms. Excel 2007 involves the production of tables and charts, and to analyze data using software Eviews 10.0. The outcomes of the data analysis of the partial hypothesis testing of CR doesn't impact company performance, DER doesn't impact company performance, CR impact the value company, DER doesn't impact the value company, company performance doesn't impact the value company. Simultaneously the $C R$ and $D E R$ are impact company performance, and CR, DER and ROA are impact the value company. From intervening variable analysis $C R$, company performance effect on the value company, company performance statistically and theoretically doesn't mediate Liquidity (CR) in affect the value of company (PBV). And for intervening variable analysis DER, company performance effect on the value company, company performance statistically and theoretically doesn't mediate Debt Policy (DER) levels in affect the value of company (PBV). 


\section{A. PENDAHULUAN}

Tidak dipungkiri setiap perusahaan pasti memiliki tujuan memperoleh laba yang maksimal. Dengan begitu, maka perusahaan dapat mempertahankan kelangsungan hidupnya dan dapat terus berkembang serta memberikan pengembalian usaha yang menguntungkan bagi kesejahteraan para pemilik, karyawan, serta meningkatkan mutu produk dan pemegang sahamnya. Namun dalam kondisi perkembangan persaingan antar perusahaan yang semakin ketat, mengharuskan perusahaan untuk meningkatkan usahanya supaya tetap bertahan. Tuntutan bagi setiap perusahaan pada kondisi persaingan saat ini untuk lebih kreatif dan inovatif baik dalam hal teknologi, kualitas produksi, sumber daya manusia serta strategi yang diterapkan harus dilakukan perusahaan untuk dapat bertahan dan bersaing antara satu perusahaan dengan perusahaan lainnya. Salah satu cara yang dapat dilakukan perusahaan agar tetap bertahan, yaitu dengan menginterpretasikan atau menganalisis keuangan, hal tersebut bertujuan agar dapat mengetahui kondisi keuangannya. Dengan kondisi keuangannya, dapat dilihat dari kinerja keuangan perusahaan dari tahun ke tahun. Pengukuran kinerja perusahaan adalah melihat laba perusahaannya. Ketidakmampuan suatu perusahaan dalam memperoleh laba akan menyebabkan tersingkirnya perusahaan dari perekonomian.

Saat ini, kebutuhan yang mungkin bisa dikatakan juga ketergantungan masyarakat Indonesia akan informasi dan komunikasi semakin tinggi, sehingga jasa telekomunikasi adalah salah satu sarana yang paling sering digunakan untuk mendapatkan informasi dan komunikasi tersebut. Oleh karena itu, sektor ini memberikan kontribusi yang signifikan bagi pertumbuhan perekonomian nasional. Melihat perkembangan seiring jamannya dunia telekomunikasi tersebut memberikan peluang bagi para investor untuk melakukan investasi di bidang industri telekomunikasi.

Penelitian ini dilakukan menggunakan industri sub sektor Telekomunikasi yang terdaftar di Bursa Efek Indonesia (BEI) selama periode 2014 - 2018. Dalam industri sub sektor Telekomunikasi terdapat 5 perusahaan yang berdiri (terakhir diperbaharui pada tanggal 31 Desember 2017), antara lain Bakrie Telecom Tbk (BTEL), XL Axiata Tbk (EXCL), Smartfren Telecom Tbk (FREN), Indosat Tbk (ISAT), dan Telekomunikasi Indonesia Tbk (TLKM).

Informasi mengenai kinerja keuangan perusahaan dapat dilihat dari laporan keuangan perusahaan. Namun, agar memperoleh informasi keuangan yang lebih relevan dengan kepentingan dan tujuan pemakai, maka informasi keuangan tersebut harus dianalisis terlebih dahulu sehingga dapat menghasilkan keputusan bisnis yang tepat. Analisis yang biasa dilakukan ialah analisis laporan keuangan. Cara yang digunakan dalam analisis laporan keuangan salah satunya dengan menggunakan rasio keuangan. Rasio keuangan yang digunakan dalam penelitian ini meliputi rasio nilai pasar, profitabilitas, solvabilitas (leverage) dan likuiditas.

Rasio nilai pasar dalam penelitian ini ditujukan kepada nilai perusahaan. Nilai perusahaan peneliti menggunakan Price Book Value (PBV) menggambarkan seberapa besar pasar menghargai nilai buku suatu saham. Semakin tinggi rasio PBV, maka akan semakin tinggi kinerja perusahaan dinilai oleh pemodal dengan dana yang telah ditanamkan di perusahaan. Oleh karena itu, disimpulkan semakin tinggi PBV, semakin tinggi tingkat kepercayaan pasar terhadap prospek perusahaan, juga semakin tinggi daya tariknya bagi investor untuk membeli saham tersebut, sehingga permintaan akan naik, dan akhirnya mendorong harga saham naik.

Faktor pertama yang dapat mempengaruhi nilai perusahaan ialah Profitabilitas. Rasio profitabilitas merupakan rasio untuk mengukur kemampuan perusahaan untuk menghasilkan laba. Menurut (Agus Sartono, 2015:122) Rasio profitabilitas adalah 
kemampuan perusahaan memperoleh laba dalam hubungannya dengan penjualan, total aktiva maupun modal sendiri. Dengan demikian bagi investor jangka panjang akan sangat berkepentingan dengan analisis profitabilitas ini misalnya bagi pemegang saham akan melihat keuntungan yang benar-benar akan diterima dalam bentuk deviden. Dalam penelitian ini profitabilitas diwakilkan dengan Return On Asset (ROA) karena dapat menunjukkan bagaimana kinerja perusahaan dilihat dari penggunaan keseluruhan aset yang dimiliki oleh perusahaan dalam menghasilkan keuntungan.

Faktor kedua yang dalam penelitian ini dapat mempengaruhi nilai perusahaan adalah solvabilitas (leverage) atau kebijakan hutang. Menurut (Kasmir, 2008:150) dalam Neni Nuraini (2017) Rasio solvabilitas (leverage) adalah rasio yang digunakan untuk menjalankan operasi perusahaan, terutama yang berkaitan dengan dana agar perusahaan dapat berjalan sebagaimana mestinya. Dalam penelitian ini solvabilitas (leverage) atau kebijakan hutang diwakilkan dengan Debt to Equity Ratio (DER). Rasio ini digunakan untuk menilai utang dengan ekuitas.

Faktor berikutnya yang dalam penelitian ini dapat mempengaruhi nilai perusahaan ialah likuiditas. Rasio likuiditas adalah kemampuan suatu perusahaan memenuhi kewajiban jangka pendeknya secara tepat waktu (Irham Fahmi, 2011:121). Perusahaan yang memiliki likuiditas yang baik maka akan dianggap memiliki kinerja yang baik oleh investor. Hal ini akan menarik minat investor untuk menanamkan modalnya pada perusahaan. Dalam penelitian ini likuiditas diukur dengan Current Ratio, merupakan rasio untuk mengukur kemampuan perusahaan dalam membayar kewajiban jangka pendek atau utang yang segera jatuh tempo. .

Berdasarkan latar belakang masalah di atas maka masalah yang akan dibahas dan dicari jawabannya dalam penelitian ini adalah :

1. Apakah Likuiditas mempengaruhi Kinerja Perusahaan?

2. Apakah Kebijakan Hutang mempengaruhi Kinerja Perusahaan?

3. Apakah Likuiditas dan Kebijakan Hutang mempengaruhi Kinerja Perusahaan?

4. Apakah Likuiditas mempengaruhii Nilai Perusahaan?

5. Apakah Kebijakan Hutang mempengaaruhi Nilai Perusahaan?

6. Apakah Kinerja Perusahaan mempengaruhi Niilai Perusahaan?

7. Apakah Likuiditas Kebijakan Hutang dan Kinerja Perusahaan mempengaruhi Nilai Perusahaan?

8. Apakah Kinerja Perusahaan memediasi antara Likuiditas terhadap Nilai Perusahaan?

9. Apakah Kinerja Perusahaan memediasi antara Kebijakan Hutang terhadap Nilai Perusahaan?

\section{B. LANDASAN TEORI}

\section{Likuiditas}

Menurut Martono dan Agus (2010:53) dalam PL Errossa (2013) "Rasio Likuiditas merupakan rasio yang menunjukkan hubungan antara kas perusahaan dan aktiva lancar lainnya dengan hutang lancar. Rasio ini digunakan untuk mengukur kemampuan perusahaan dalam memenuhi kewajiban-kewajiban finansialnya yang harus segera dipenuhi atau kewajiban jangka pendek". Menurut Sitanggang (2012:22) "Likuiditas merupakan ukuran kinerja perusahaan dalam kemampuan perusahaan untuk memenuhi kewajiban keuangan yang segera harus dilunasi yaitu kewajiban keuangan yang jatuh temponya sampai dengan 1 tahun".

\section{Kebijakan Hutang}

Dalam mengukur kebijakan hutang, menggunakan rasio keuangan yaitu Rasio Leverage/Solvabilitas. Menurut Martono dan Agus (2010:53) dalam PL Errossa (2013) "Rasio Leverage adalah rasio yang mengukur seberapa banyak perusahaan menggunakan dana dari hutang (pinjaman)". Menurut Sitanggang (2012:25) "Rasio 
Leverage merupakan ukuran seberapa besar perusahaan dibiayai dari unsur utang, dan seberapa besar kemampuan perusahaan dari hasil operasi perusahaan untuk melunasi beban pembayaran bunga dan atau pokok pinjaman tersebut".

\section{Kinerja Perusahaan}

Pada penelitian ini untuk kinerja perusahaan, menggunakan Rasio Profitabilitas. Menurut Kasmir (2014:196) "Rasio ini juga memberikan ukuran tingkat efektivitas manajemen suatu perusahaan". Menurut Fahmi (2011:135) "Rasio ini mengukur efektivitas manajemen secara keseluruhan yang ditujukan oleh besar kecilnya tingkat keuntungan yang diperoleh dalam hubungannya dengan penjualan maupun investasi".

\section{Kerangka Berpikir}

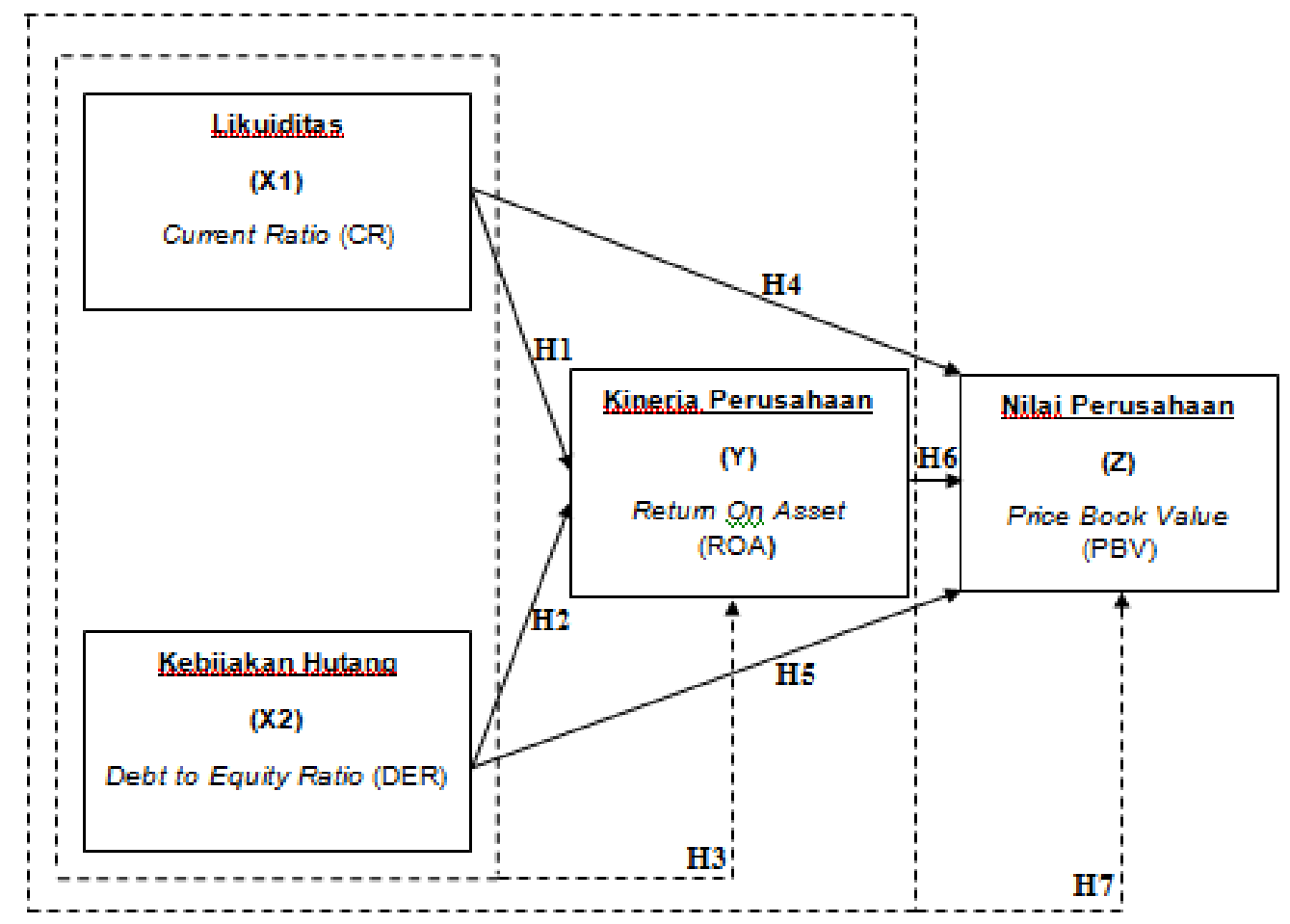

(Variabel. Independen)

(Variabel. Intervening)

(Variabel.Dependen)

Keterangan:

$\begin{array}{ll}\text { X1 } & =\text { Likuiditas (CR) } \\ \text { X2 } & =\text { Kebijakan Hutang (DER) } \\ \text { Y } & =\text { Kinerja Perusahaan (ROA) } \\ \text { Z } & =\text { Nilai Perusahaan (PBV) }\end{array}$

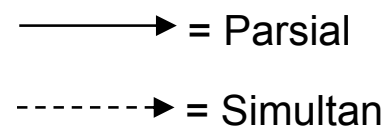

\section{Hipotesis Penelitian}

$\mathrm{Ha}_{1}$ : Likuiditas memiliki pengaruh terhadap Kinerja Perusahaan .

$\mathrm{Ha}_{2}$ : Kebijakan Hutang memiliki pengaruh terhadap Kinerja Perusahaan .

$\mathrm{Ha}_{3}$ : Likuiditas dan Kebijakan Hutang memiliki pengaruh secara simultan terhadap Kinerja Perusahaan

$\mathrm{Ha}_{4}$ : Likuiditas memiliki pengaruh terhadap Nilai Perusahaan"

$\mathrm{Ha}_{5}$ : Kebijakan Hutang memiliki pengaruh terhadap Nilai Perusahaan .

$\mathrm{Ha}_{6}$ : Kinerja Perusahaan memiliki pengaruh terhadap Nilai Perusahaan .

$\mathrm{Ha}_{7}$ : Likuiditas, Kebijakan Hutang dan Kinerja Perusahaan memiliki pengaruh secara simultan terhadap Nilai Perusahaan . 


\section{METODOLOGI PENELITIAN}

Jenis penelitian dalam penyusunan skripsi ini bersifat deskriptif dan memakai pendekatan kuantitatif yang artinya masing-masing variabel ataupun antar variabel didasari skala pengukuran kuantitatif. Populasi yang digunakan pada penelitian ini ialah perusahaan Sub Sektor Telekomunikasi yang terdaftar di Bursa Efek Indonesia (BEI) pada periode tahun 2014-2018 dengan situs web www.idx.co.id. Pada penarikan sampel penelitian memakai desain non probability sampling (sampel non profitabilitas) dengan teknik purposive sampling di mana pada teknik ini dalam penentuan sampel dilakukan dengan adanya suatu pertimbangan tertentu atau adanya suatu kriteria yang ditentukan (Sugiyono 2015:85). Kriteria penarikan sampel yang dipergunakan oleh peneliti antara lain:

1. Perusahaan Sub Sektor Telekomunikasi yang terdaftar di Bursa Efek Indonesia (BEI).

2. Perusahaan Sub Sektor Telekomunikasi yang memiliki laporan keuangan lengkap selama periode tahun 2014-2018.

\section{Sampel Penelitian ini adalah:}

\begin{tabular}{|c|l|l|}
\hline No & Kode & Nama Perusahaan \\
\hline 1 & BTEL & PT. Bakrie Telecom Tbk \\
\hline 2 & EXCL & PT. XL Axiata Tbk \\
\hline 3 & FREN & PT. Smartfren Telecom Tbk \\
\hline 4 & ISAT & PT. Indosat Tbk \\
\hline 5 & TLKM & PT. Telekomunikasi Indonesia Tbk \\
\hline
\end{tabular}

Sumber: IDX Sub Sektor Telekomunikasi Periode Tahun 2014-2018

Operasional Variabel Penelitian ini adalah:

\begin{tabular}{|c|c|c|c|}
\hline Variabel & Proksi & Pengukuran & Skala \\
\hline $\begin{array}{l}\text { Likuiditas } \\
\text { (X1) }\end{array}$ & $\begin{array}{c}\text { Current } \\
\text { Ratio (CR) }\end{array}$ & $C R=\frac{\text { Aktiva Lancar }}{\text { Utang Lancar }} \mathrm{X} 100 \%$ & Rasio \\
\hline $\begin{array}{l}\text { Kebijakan } \\
\text { Hutang (X2) }\end{array}$ & $\begin{array}{l}\text { Debt to } \\
\text { Equity Ratio } \\
\text { (DER) }\end{array}$ & $D E R=\frac{\text { Total Utang }}{\text { Total Ekuitas }} \times 100 \%$ & Rasio \\
\hline $\begin{array}{l}\text { Kinerja } \\
\text { Perusahaan } \\
\text { (Y) }\end{array}$ & $\begin{array}{l}\text { Return on } \\
\text { Assets } \\
\text { (ROA) }\end{array}$ & $R O A=\frac{\text { Laba Bersih Setelah Pajak }}{\text { Total Aset }} \times 100 \%$ & Rasio \\
\hline $\begin{array}{l}\text { Nilai } \\
\text { Perusahaan } \\
(\mathrm{Z})\end{array}$ & $\begin{array}{l}\text { Price Book } \\
\text { Value } \\
\text { (PBV) }\end{array}$ & $P B V=\frac{\text { Harga Pasar per Saham }}{\text { Nilai Buku per Saham }}$ & Rasio \\
\hline
\end{tabular}

Teknik analisis data yang dilakukan memakai metode analisis regresi linear berganda data panel. Adapun tahapan dalam menganalisis regresi linear berganda data panel terdiri dari penentuan model estimasi, penentuan metode estimasi, uji asumsi klasik dan uji hipotesis. Untuk memilih salah satu dari tiga pendekatan regresi 
panel (model estimasi) yang akan dipergunakan ialah ordinary least square (OLS) atau common effect model, metode efek tetap (fixed effect model), dan metode efek random (random effect model). Maka dilakukan Chow test serta Hausman test dengan teknik estimasi path analisis (Nardi Sunardi, 2016). Untuk mengolah data sekunder yang didapat, peneliti memakai aplikasi antara lain, MS. Excel 2007 mencakup pembuatan tabel serta grafik untuk analisis deskriptif. Sedangkan pengolahan data dengan EVIEWS versi 10.0 untuk membantu menganalisis data yang dipergunakan dalam melakukan pengujian signifikasi analisis regresi linier berganda data panel .

\section{HASIL DAN PEMBAHASAN}

Estimasi terhadap faktor-faktor yang mempengaruhi nilai perusahaan dalam penelitian ini di perusahaan sub sektor Telekomunikasi yang terdaftar di-Bursa Efek Indonesia (BEI) selama periode tahun 2014-2018 .

Dalam menganalisis estimasi perlu diuraikan terlebih dahulu deskripsi data tiap variabel pada penelitian ini. Deskripsi statistik variabel pada penelitian ini ditunjukkan sebagai berikut:

\section{Deskripsi Data Statistik}

\begin{tabular}{lllll}
\hline & PBV & ROA & CR & DER \\
\hline Mean & 1.787287 & -0.321915 & 0.513619 & 2.005730 \\
Median & 1.164082 & -0.035259 & 0.452487 & 1.608476 \\
Maximum & 4.855565 & 0.111571 & 1.352949 & 3.669497 \\
Minimum & 0.110038 & -3.583003 & 0.000160 & 0.824412 \\
Std. Dev. & 1.542547 & 0.833021 & 0.382072 & 1.013649 \\
Skewness & 0.748262 & -2.936578 & 0.520544 & 0.300512 \\
Kurtosis & 2.276090 & 11.11707 & 2.582123 & 1.514609 \\
Jarque-Bera & 2.878781 & 104.5633 & 1.310924 & 2.674601 \\
Probability & 0.237072 & 0.000000 & 0.519202 & 0.262554 \\
Sum & 44.68217 & -8.047865 & 12.84047 & 50.14324 \\
Sum Sq. Dev. & 57.10686 & 16.65418 & 3.503493 & 24.65965 \\
\hline Observations & 25 & 25 & 25 & 25 \\
\hline \multicolumn{2}{c}{ Sumber: Hasil Olah Data Panel Eviews 10.0} & &
\end{tabular}

\section{Pemilihan Model Variabel Dependen Nilai Perusahaan pada Regresi Data Panel}

Pemilihan Model Variabel Dependen Nilai Perusahaan yang dipergunakan pada penelitian ini berdasarkan atas tiga model yaitu diantaranya: (1) metode ordinary least square (OLS) atau common effect model (CEM), (2) metode efek tetap (fixed effect model (FEM)), serta (3) metode efek random (random effect model (REM)). Berikut ialah aplikasi dari pemilihan model yang ditetapkan terhadap model regresi data panel menggunakan nilai perusahaan yang diwakilkan dengan Price Book Value (PBV).

\section{Kesimpulan Model}

Sesuai dengan pengujian berpasangan terhadap ketiga model regresi data panel, bisa disimpulkan bahwa model efek tetap pada regresi data panel yang dipergunakan lanjut pada mengestimasi faktor-faktor yang mempengaruhi price book value terhadap 5 perusahaan sub sektor Telekomunikasi yang terdaftar di Bursa Efek Indonesia (BEI) yang dijadikan sampel penelitian selama periode 20142018. 
Hasil kesimpulan Pengujian dengan Regresi Data Panel

\begin{tabular}{|r|c|c|c|}
\hline No. & Metode & Pengujian & Hasil \\
\hline 1. & Chow-Test" & $\begin{array}{c}\text { Common Effect Model vs } \\
\text { Fixed Effect Model }\end{array}$ & Fixed Effect Model \\
\hline 2. & Hausman Test & $\begin{array}{c}\text { Random Effect Model vs } \\
\text { Fixed Effect Model }\end{array}$ & Fixed Effect Model \\
\hline 3. & $\begin{array}{c}\text { Langrage } \\
\text { Multiplier (LM- } \\
\text { test) }\end{array}$ & $\begin{array}{c}\text { Common Effect Model vs } \\
\text { Random Effect Model }\end{array}$ & $\begin{array}{c}\text { Random Effect } \\
\text { Model }\end{array}$ \\
\hline
\end{tabular}

\section{Rekap Hasil Data Panel untuk Fixed Effect Model}

Untuk memilih model terbaik untuk dianalisis lanjut dalam mengestimasi regresi data panel memakai kriteria koefisien determinasi $R^{2}$ dan koefisien determinasi yang disesuaikan $\mathrm{R}^{2}$. Dari hasil perhitungan menyimpulkan bahwa model efek tetap lebih baik dari kedua model regresi data panel yang lain dalam mengestimasi faktorfaktor yang mempengaruhi nilai perusahaan (PBV) pada perusahaan Telekomunikasi yang terdaftar di Bursa Efek Indonesia (BEI) selama tahun 20142018. Hasil variabel yang mempengaruhi Nilai Perusahaan (PBV) ialah, Likuiditas (CR), Kebijakan Hutang (DER) serta Kinerja Perusahaan (ROA)" metode Panel Least Squares antara lain:

Variabel dependen: PBV

\begin{tabular}{cclll}
\hline \hline \multicolumn{1}{c}{ Variabel } & Coefficien & Stdr. Error & t-Statistik & Prob. \\
\hline \hline CR & 2.431835 & 0.916499 & 2.653396 & 0.0167 \\
DER & 0.034749 & 0.155867 & 0.222937 & 0.8262 \\
ROA & 0.037097 & 0.190801 & 0.194430 & 0.8481 \\
C & 0.480497 & 0.498530 & 0.963827 & 0.3486 \\
\hline \hline R-squared & 0.933958 & Mean dependent var & 1.787287 \\
Adjusted R-squared & 0.906764 & S.D. dependent var & 1.542547 \\
S.E. of regression & 0.471011 & Akaike info criterion & 1.586465 \\
Sum squared resid & 3.771466 & Schwarz criterion & 1.976505 \\
Log likelihood & -11.83081 & Hannan-Quinn criter . & 1.694646 \\
F-statistic & 34.34442 & Durbin-Watson stat & 1.842848 \\
Prob(F-statistic) & 0.000000 & & \\
\hline \hline
\end{tabular}


Hasil Kesimpulan hitungan Regresi Data Panel untuk fixed efek model sebagai berikut:

\begin{tabular}{|r|r|c|c|c|c|l|}
\hline No. & Model & $\begin{array}{c}\text { Adjusted } \\
\text { R- } \\
\text { squared }\end{array}$ & $\begin{array}{c}\text { F- } \\
\text { statistic }\end{array}$ & $\begin{array}{c}\text { Prob (F- } \\
\text { statistic) } \\
\alpha=0,01\end{array}$ & \multicolumn{2}{|c|}{ Probabilitas $\alpha=0,05$} \\
\hline \multirow{2}{*}{1} & $\begin{array}{c}\text { Fixed } \\
\text { Effect }\end{array}$ & 0,9067 & 34.3444 & 0.0000 & ROA & Tidak Signifikan \\
\cline { 5 - 7 } & & & & SER & Signifikan \\
\hline
\end{tabular}

Hasil Uji Model secara Parsial (Uji t) dan Simultan (Uji F) terhadap Variabel Dependen Nilai Perusahaan.

\section{Estimasi Model Regresi Data Panel Secara Parsial (Uji t)}

Uji-t akan dilakukan dengan dua tahap uji bagi tiap variabel bebas pada model penelitian ini, ialah uji signifikan dengan probability atas $p$-value dan uji arah atas nilai koefisiennya.

- Hipotesis 1 (Likuiditas (CR) terhadap Kinerja Perusahaan (ROA)).

Berdasarkan Uji-t menunjukkan bahwa variabel Current ratio (CR) dengan koefisien $C R=0.108563$ positif $(+)$ dengan probabilitas sebesar 0.9214 lebih besar dari 0.05 atau $5 \%$ oleh karena itu, hipotesis yang diusulkan ditolak atau dikatakan tidak signifikan terhadap kinerja perusahaan (ROA) pada perusahaan Telekomunikasi yang terdaftar di Bursa Efek Indonesia (BEI) selama periode 2014-2018. Hasil penelitian ini memperlihatkan positif serta tidak signifikan dengan taraf keyakinan sebanyak 0.608340 atau 60,83 persen dan sisanya 39,17 persen dipengaruhi oleh faktor lain diluar model ini. Serta dengan nilai probabilitas (0.9214) lebih dari $\alpha=0,05$ yang berarti $\mathrm{H} 1$ ditolak atau positif dan tidak signifikan. Interpretasinya ialah apabila current ratio (CR) naik 1\% maka pengaruh terhadap return on asset (ROA) turun sebanyak 0.100036 dan memiliki pengaruh tidak signifikan. Begitupun sebaliknya

- Hipotesis 2 (Kebijakan Hutang (DER) terhadap Kinerja Perusahaan (ROA)).

Berdasarkan Uji-t memperlihatkan bahwa variabel debt to equity ratio (DER) dengan koefisien DER $=0.195796$ positif $(+)$ dengan probabilitas sebanyak 0.2718 lebih besar dari 0.05 atau $5 \%$ oleh karena itu, hipotesis yang diusulkan ditolak atau dikatakan tidak signifikan terhadap kinerja perusahaan (ROA) pada perusahaan Telekomunikasi yang terdaftar di Bursa Efek Indonesia (BEI) selama periode 2014-2018. Hasil penelitian ini memperlihatkan positif dan tidak signifikan dengan taraf keyakinan sebanyak 0.632884 atau 63,28 persen dan sisanya 36,72 persen dipengaruhi oleh faktor lain diluar model ini. Serta dengan nilai probabilitas (0.2718) lebih dari $\alpha=0,05$ yang berarti $\mathrm{H} 1$ ditolak atau positif dan tidak signifikan. Interpretasinya ialah apabila debt to equity ratio (DER) naik $1 \%$ maka pengaruh terhadap return on asset (ROA) turun sebanyak 1.131783 dan memiliki pengaruh tidak signifikan. Begitupun sebaliknya. 
- Hipotesis 3 (Likuiditas (CR) dan Kebijakan Hutang (DER) terhadap Kinerja Perusahaan (ROA)).

Hasil Uji-F memperlihatkan bahwa variabel Current ratio (CR) dan debt to equity ratio (DER) dengan F-statistik sebesar 5.198683 dengan nilai probabilitas sebesar 0.002916 lebih kecil dari 0,05 atau 5\% oleh karena itu, hipotesis yang diusulkan diterima atau dikatakan signifikan terhadap kinerja perusahaan (ROA) pada perusahaan Telekomunikasi yang terdaftar di Bursa Efek Indonesia (BEI) selama periode 2014-2018. Hasil penelitian ini memperlihatkan positif dan signifikan dengan taraf keyakinan sebanyak 0.634088 atau 63,40 persen dan sisanya 36,6 persen dipengaruhi oleh faktor lain diluar model ini. Demikian nilai probabilitas Fstatistik (0.002916) kurang dari $\alpha=0,05$ yang berarti $\mathrm{H} 1$ diterima atau positif dan signifikan.

- Hipotesis 4 (Likuiditas (CR) terhadap Nilai (PBV)).

Hasil Uji-t memperlihatkan bahwa variabel current ratio (CR) dengan koefisien $\mathrm{CR}=2.499506$ positif (+) dengan probabilitas sebanyak 0.0071 lebih kecil dari 0.05 atau $5 \%$ oleh karena itu, hipotesis yang diusulkan diterima atau dikatakan signifikan terhadap nilai perusahaan (PBV) pada perusahaan Telekomunikasi yang terdaftar di Bursa Efek Indonesia (BEI) selama periode 2014-2018. Hasil penelitian ini memperlihatkan positif dan signifikan dengan taraf keyakinan sebanyak 0.933501 atau 93,35 persen dan sisanya 6,65 persen dipengaruhi oleh faktor lain diluar model ini. Serta dengan nilai probabilitas $(0.0071)$ kurang dari $\alpha=0,05$ yang berarti $\mathrm{H} 1$ diterima atau positif dan signifikan. Interpretasinya ialah apabila current ratio (CR) naik 1\% maka pengaruh terhadap price book value (PBV) turun sebanyak 3.018542 dan memiliki pengaruh signifikan. Begitupun sebaliknya.

- Hipotesis 5 (Kebijakan Hutang (DER) terhadap Nilai Perusahaan (PBV)).

Berdasarkan Uji-t menunjukkan bahwa variabel debt to equity ratio (DER) dengan koefisien DER $=0.162763$ positif $(+)$ dengan probabilitas sebanyak 0.3264 lebih besar dari 0.05 atau $5 \%$ oleh karena itu, hipotesis yang diusulkan ditolak atau dikatakan tidak signifikan terhadap nilai perusahaan (PBV) pada perusahaan Telekomunikasi yang terdaftar di Bursa Efek Indonesia (BEI) selama periode 2014-2018. Hasil penelitian ini memperlihatkan positif dan tidak signifikan dengan taraf keyakinan sebanyak 0.906599 atau 90,65 persen dan sisanya 9,35 persen dipengaruhi oleh faktor lain diluar model ini. Serta dengan nilai probabilitas (0.3264) lebih dari $\alpha=0,05$ yang berarti $\mathrm{H} 1$ ditolak atau positif dan tidak signifikan. Interpretasinya ialah apabila debt to equity ratio (DER) naik $1 \%$ maka pengaruh terhadap price book value (PBV) turun sebanyak 1.007305 dan memiliki pengaruh tidak signifikan. Begitupun sebaliknya.

- Hipotesis 6 (Kinerja Perusahaan (ROA) terhadap Nilai Perusahaan (PBV)).

Hasil Uji-t memperlihatkan bahwa variabel return on asset (ROA) dengan koefisien $\mathrm{ROA}=0.060098$ positif (+) dengan probabilitas sebanyak 0.7803 lebih besar dari 0.05 atau $5 \%$ oleh karena itu, hipotesis yang diusulkan ditolak atau dikatakan tidak signifikan terhadap nilai perusahaan (PBV) pada perusahaan Telekomunikasi yang terdaftar di Bursa Efek Indonesia (BEI) selama periode 2014-2018. Hasil penelitian ini memperlihatkan 
positif dan tidak signifikan dengan taraf keyakinan sebanyak 0.902024 atau 90,20 persen dan sisanya 9,8 persen dipengaruhi oleh faktor lain diluar model ini. Serta dengan nilai probabilitas (0.7803) lebih dari $\alpha=0,05$ yang berarti $\mathrm{H} 1$ ditolak atau positif dan tidak signifikan. Interpretasinya ialah apabila return on asset (ROA) naik $1 \%$ maka pengaruh terhadap price book value (PBV) turun sebanyak 0.282922 dan memiliki pengaruh tidak signifikan. Begitupun sebaliknya

\section{Estimasi Model Regresi Data Panel Secara Simultan (Uji F)}

- Hipotesis 7 (Likuiditas (CR), Kebijakan Hutang (DER) dan Kinerja Perusahaan (ROA) secara bersama-sama terhadap Nilai Perusahaan yang diwakilkan dengan (PBV)).

Hasil Uji-F memperlihatkan bahwa variabel return on asset (ROA), current ratio (CR), dan debt to equity ratio (DER) dengan nilai F-statistik sebanyak 34.34442 dengan nilai probabilitas sebesar 0.000000 lebih kecil dari 0,05 atau $5 \%$ oleh karena itu, hipotesis yang diusulkan diterima atau dikatakan signifikan terhadap nilai perusahaan yang diwakilkan price book value (PBV) pada perusahaan Telekomunikasi yang terdaftar di Bursa Efek Indonesia (BEI) selama periode 2014-2018. Hasil penelitian ini memperlihatkan positif dan signifikan dengan taraf keyakinan sebanyak 0.933958 atau 93,39 persen dan sisanya 6,61 persen dipengaruhi oleh faktor lain diluar model ini. Demikian nilai probabilitas F-statistik (0.000000) kurang dari $\alpha=0,05$ yang berarti $\mathrm{H} 1$ diterima atau positif dan signifikan.

Pengujian Intervening Kinerja Perusahaan (ROA) terhadap Nilai Perusahaan (PBV).

\section{Penjelasan Analisis Mediasi (Intervening)}

a. $\mathrm{CR}>\mathrm{ROA}>\mathrm{PBV}$

$\mathrm{c}^{2}<\mathrm{a} \times \mathrm{b}$ (memediasi), $\mathrm{c}^{2}>\mathrm{a} \times \mathrm{b}$ (tidak memediasi)

$2.499506^{2}><(0.108563) \times(0.060098)$

$6.2475302440>0.0065244191$ (tidak memediasi)

Variabel current ratio (CR) dapat mempengaruhi langsung ke variabel ROA serta dapat juga tak langsung ke variabel ROA (variabel intervening) kemudian ke variabel PBV. Besar pengaruh langsung ialah $2.499506^{2}=$ 6.2475302440 dan besar pengaruh tak langsung ialah $(0.108563) \times$ $(0.060098)=0.0065244191$. Dikarenakan besarnya pengaruh langsung lebih besar dari besarnya pengaruh tidak langsung (6.2475302440 > 0.0065244191 ), bisa disimpulkan bahwa hubungan sesungguhnya ialah langsung. Dengan demikian, return on asset (ROA) secara statistik dan teoritis tidak memediasi tingkat Likuiditas yang diwakilkan dengan current ratio (CR) dalam mempengaruhi Nilai Perusahaan yang diwakilkan dengan price book value (PBV) .

b. DER > ROA > PBV

$\mathrm{c}^{2}<\mathrm{a} \times \mathrm{b}$ (memediasi), $\mathrm{c}^{2}>\mathrm{a} \times \mathrm{b}$ (tidak memediasi)

$0.162763^{2}><(0.195796) \times(0.060098)$

$0.0264917941>0.0117669480$ (tidak memediasi)

Variabel debt to equity ratio (DER) dapat memiliki pengaruh langsung ke variabel $R O A$ dan dapat juga memiliki pengaruh tidak langsung ke variabel ROA (sebagai variabel intervening) lalu ke variabel PBV. Besarnya pengaruh langsung adalah $0.162763^{2}=0.0264917941$ dan besarnya pengaruh tidak langsung adalah $(0.195796) \times(0.060098)=0.0117669480$. 
Oleh karena besarnya pengaruh langsung lebih besar dari besarnya pengaruh tidak langsung (0.0264917941 $>0.0117669480)$, bisa disimpulkan bahwa hubungan sesungguhnya ialah langsung. Dengan demikian, return on asset (ROA) secara statistik dan teoritis tidak memediasi tingkat Kebijakan Hutang yang diwakilkan dengan debt to equity ratio (DER) dalam mempengaruhi Nilai Perusahaan yang diwakilkan dengan price book value (PBV) .

\section{Pembahasan Hasil Pengujian Mediasi Determinan Kinerja Perusahaan Terhadap Nilai Perusahaan}

Secara detail pembahasan terhadap hasil pengujian mediasi dilakukan antara lain:

a. Likuiditas memiliki pengaruh positif dan tidak signifikan terhadap kinerja perusahaan, dan memiliki pengaruh positif dan signifikan terhadap nilai perusahaan.

b. Kebijakan Hutang memiliki pengaruh positif dan tidak signifikan terhadap kinerja perusahaan dan memiliki pengaruh positif dan tidak signifikan terhadap nilai perusahaan.

c. Kinerja Perusahaan memiliki pengaruh positif dan tidak signifikan terhadap nilai perusahaan.

Dari penjabaran diatas, sehingga bisa diterangkan beberapa hal berikut:

Pertama, likuiditas memiliki pengaruh positif dan tidak signifikan terhadap kinerja perusahaan, dan signifikan terhadap nilai perusahaan. Hasil analisis jalur (path analysis) memperlihatkan pengaruh likuiditas terhadap nilai perusahaan ialah pengaruh langsung. Dikarenakan besarnya pengaruh tidak langsung lebih kecil dari besarnya pengaruh langsung, dan bisa disimpulkan bahwa hubungan sesungguhnya ialah langsung. Dengan demikian, kinerja perusahaan secara statistik dan teoritis tidak memediasi likuiditas dalam mempengaruhi nilai perusahaan. Sehingga kinerja perusahaan tidak berfungsi sebagai variabel intervening dari likuiditas dalam mempengaruhi nilai perusahaan. Disimpulkan kembali bahwa kinerja perusahaan berkedudukan sebagai variabel intervening tidak memediasi pengaruh likuiditas dalam mempengaruhi nilai perusahaan. Oleh sebabnya, dalam model ini terjadi pengaruh tidak bertahap antara likuiditas, kinerja perusahaan, dan nilai perusahaan .

Kedua, kebijakan hutang memiliki pengaruh positif dan tidak signifikan terhadap kinerja perusahaan dan memiliki pengaruh positif dan tidak signifikan terhadap nilai perusahaan. Hasil analisis jalur (path analysis) memperlihatkan bahwa pengaruh kebijakan hutang terhadap nilai perusahaan ialah pengaruh langsung. Dikarenakan besarnya pengaruh tidak langsung lebih kecil dari besarnya pengaruh langsung, dan bisa disimpulkan bahwa hubungan sesungguhnya ialah langsung. Dengan demikian, kinerja perusahaan secara statistik dan teoritis tidak memediasi kebijakan hutang dalam mempengaruhi nilai perusahaan. Sehingga kinerja perusahaan tidak berfungsi sebagai variabel intervening dari kebijakan hutang dalam mempengaruhi nilai perusahaan. Disimpulkan kembali bahwa kinerja perusahaan berkedudukan sebagai variabel intervening tidak memediasi pengaruh kebijakan hutang dalam mempengaruhi nilai perusahaan. Oleh sebabnya, dalam model ini terjadi pengaruh tidak bertahap antara kebijakan hutang, kinerja perusahaan, dan nilai perusahaan . 


\section{E. KESIMPULAN}

1. Likuiditas memiliki pengaruh positif dan tidak signifikan terhadap Kinerja Perusahaan

2. Kebijakan Hutang memiliki pengaruh positif dan tidak signifikan terhadap Kinerja Perusahaan

3. Likuiditas dan Kebijakan Hutang secara simultan memiliki pengaruh positif dan signifikan terhadap Kinerja Perusahaan

4. Likuiditas memiliki pengaruh positif dan signifikan terhadap Nilai Perusahaan

5. Kebijakan Hutang memiliki pengaruh positif dan tidak signifikan terhadap Nilai Perusahaan

6. Kinerja Perusahaan memiliki pengaruh positif dan tidak signifikan terhadap Nilai Perusahaan

7. Likuiditas, Kebijakan Hutang dan Kinerja Perusahaan secara simultan memiliki pengaruh positif dan signifikan terhadap Nilai Perusahaan.

Saran dikhususkan untuk peneliti selanjutnya berkaitan lebih membangun penelitian ini guna menjadi variasi yang berbeda dari lainnya serta hasil lebih maksimal dengan faktor yang memiliki pengaruh pada nilai perusahaan. Berikut sarannya:

1. Bagi Perusahaan

Diharapkan perusahaan yang menjadi subjek dalam penelitian ini maupun diluar penelitian untuk dapat memperhatikan faktor-faktor tersebut guna mengoptimalkan kinerja perusahaan atau meningkatkan nilai perusahaan. Sehingga yang dapat dilakukan manajer keuangan ialah meningkatkan profit lebih besar agar dapat meningkatkan kinerja maupun nilai perusahaan.

2. Bagi Investor

Sebaiknya diharuskan selalu fokus pada kinerja perusahaan, sebab perusahaan yang memiliki kinerja perusahaan tinggi diharapkan bisa membayar deviden sehingga dapat memberikan kemakmuran para pemegang saham.

3. Bagi Peneliti Selanjutnya

Diharapkan untuk bisa lebih disempurnakan dan dikembangkan dengan sampel perusahaan lebih banyak lagi yang mencakup semua jenis perusahaan yang terdaftar di Bursa Efek Indonesia. Harapan hasil penelitian nantinya, agar mengetahui apakah faktor-faktor memiliki pengaruh terhadap nilai perusahaan sama atau akan berbeda antar sektor di luar ruang lingkup industri sub sektor Telekomunikasi. Kemudian, disarankan juga untuk memperluas variabel keuangan lain yang memiliki pengaruh lebih besar terhadap nilai perusahaan.

\section{DAFTAR PUSTAKA}

Brigham, EF \& Houston, JF. (2010). Dasar - Dasar Manajemen Keuangan. Buku Satu (Edisi 11). Jakarta: Salemba Empat.

Fahmi, Irham. (2014). Analisis Laporan Keuangan. Bandung: Alfabeta.

Ghozali, I. (2013). Aplikasi Analisis Multivariate Dengan Program IBM SPSS 19. Edisi Ketujuh. Semarang : Universitas Diponegoro.

Hanafi, MM \& Halim. (2012). Analisis Laporan Keuangan. Edisi Keempat, cetakan kedua. Yogyakarta: UPP STIM YKPN.

Handoko, T. Hani. (2011). Manajemen Personalia dan Sumber Daya Manusia. Yogyakarta: BPFE.

Harjito A. \& Martono. (2012). Manajemen Keuangan. Edisi Kedua. Yogyakarta: Ekonisia. 
Harmono. (2011). Manajemen Keuangan Berbasis Blanced Scoredcard Pendekatan Teori, Kasus, dan Riset Bisnis. Edisi Kesatu. Jakarta: Bumi Aksara.

Harmono. (2016). Manajemen Keuangan Berbasis Balanced Scorecard Pendekatan Teori, Kasus, dan Riset Bisnis. Edisi Kelima. Jakarta: Bumi Aksara.

Jogiyanto. (2003). Teori Portofolio dan Analisis Investasi. Edisi Ketiga. Yogyakarta: BPFE.

Kasmir. (2015). Analisis Laporan Keuangan. Edisi Kesatu, cetakan kedelapan. Jakarta: PT. Raja Grafindo Persada.

R. Terry, George. (2010). Dasar - Dasar Manajemen. Cetakan Kesebelas. Jakarta: PT. Bumi Aksara.

R. Terry, George \& W. Rue, Leslie. (2016). Dasar - Dasar Manajemen. Jakarta: PT. Bumi Aksara.

Rosadi, Dedi. (2012). Ekonometrika \& Analisis Runtun Waktu Terapan dengan EViews. Yogyakarta: C.V Andi Offset.

Sartono, A. (2010). Manajemen Keuangan Teori dan Aplikasi. Edisi Keempat. Yogyakarta: BPFE.

Sartono, A. (2015). Manajemen Keuangan Teori dan Aplikasi. Edisi Keempat. Yogyakarta: Sitanggang, J. (2014). Manajemen Keuangan Perusahaan. Edisi Kedua. Jakarta: Mitra Wacana Media.

Sudana, I. M. (2011). Manajemen Keuangan Perusahaan. Jakarta: Erlangga.

Sugiyono. (2015). Metode Penelitian Kuantitatif Kualitatif dan R\&D. Bandung: Alfabeta.

Agustiani, Titik. (2018). Pengaruh ROA, DER, dan CR Terhadap Nilai Perusahaan Sektor Manufaktur yang Terdaftar di Bursa Efek Indonesia Periode 2014-2016. Universitas Nusantara PGRI Kediri.

Anggraini, Ratih. (2015). Analisis Pengaruh Price Earning Ratio, Debt to Equity Ratio, Return On Asset, Current Ratio, dan Firm Size Terhadap Nilai Perusahaan (PBV) (Studi pada Perusahaan Sektor Property Real Estate \& Building Construction Tahun 2008-2012). Jurnal Universitas Dian Nuswantoro Semarang.

Annisa, Rizki, \& Chabachib M. (2017). Analisis Pengaruh CR, DER, ROA Terhadap Price to Book Value (PBV), dengan Dividen Payout Ratio sebagai Variabel Intervening (Studi Kasus pada Perusahaan Industri Manufaktur yang Terdaftar di BEI Periode 2011-2014). Diponegoro Journal of Management, 6(1).

Aprilia, Ratna S., R. (2018). Pengaruh Current Ratio, Total Asset Turn Over dan Debt to Equity Ratio Terhadap Price to Book Value dengan Return On Asset Sebagai Variabel Intervening (Studi pada Perusahaan Sektor Industri Barang Konsumsi di Bursa Efek Indonesia Periode 2013-2017). Universitas Jember.

Denixartika. (2018). Pengaruh Rasio Profitabilitas, Rasio Likuiditas, Rasio Aktivitas, Struktur Modal dan Ukuran Perusahaan Terhadap Nilai Perusahaan pada Perusahaan Pertambangan Batubara di Bursa Efek Indonesia Tahun 2013-2016. Jurnal UIN Sultan Syarif Kasim Riau.

Dzunurain, Ahmad. (2014), Pengaruh Profitabilitas Dan Ukuran Perusahaan Terhadap Pengeluaran Zakat. Universitas Pendidikan Idonesia.

Eliza, \& Sudirgo, Tony. (2019). Analisis Likuiditas, Profitabilitas, Kebijakan Hutang Terhadap Nilai Perusahaan yang Terdaftar di BEI. Jurnal Multiparadigma Akuntansi, 1(3).

Errossa, Pitria Liza. (2013), Pengaruh Current Ratio dan Total Debt to Total Assets Terhadap Net Profit Margin. Universitas Widyatama Bandung Jurnal Bab II.

Harfain, Ibnu. (2019). Pengaruh Current Ratio, Debt to Asset Ratio, dan Total Asset Turn Over Terhadap Return On Asset pada Perusahaan Sub Sektor Telekomunikasi yang Terdaftar di Bursa Efek Indonesia. Universitas Muhammadiyah Jakarta.

Hasan, Ibrahim. (2019). Pengaruh Likuiditaas dan Solvabilitas Terhadap Profitabilitas pada PT. Surya Toto Indonesia Tbk. Universitas Pamulang.

Julianti, Dewi. (2014). Pengaruh Rasio Hutang (DER) dan Profitabilitas (ROA) Terhadap Nilai Perusahaan (PBV) (Studi Kasus pada Perusahaan Manufaktur Sub Sektor 
Otomotif dan Komponen yang Terdaftar di Bursa Efek Indonesia Periode 20122014). Universitas Komputer Indonesia.

Kalsum, Umi. (2017). Pengaruh Ukuran Perusahaan, Likuiditas, Kinerja Keuangan dan Kebijakan Hutang Terhadap Nilai Perusahaan pada Perusahaan Perbankan di Bursa Efek Indonesia (BEI). Jurnal Ekonomi Universitas Muhammadiyah Sumatera Utara, 8(1).

Khairunnisa, T., Taufik, \& Thamrin Husni, K., M. (2019). Pengaruh DER, ROA, Assets Growth, CR, dan TATO Terhadap Nilai Perusahaan pada Perusahaan Sektor Makanan dan Minuman yang Terdaftar di BEI. Jurnal IImiah Manajemen Bisnis dan Terapan Universitas Sriwijaya, 14(1).

Nuraini, Neni. (2017). Pengaruh Profitabilitas, Likuiditas dan Kebijakan Hutang Terhadap Nilai Perusahaan pada PT. Indofood Sukses Makmur, Tbk. Universitas Pamulang.

Nurkarima, Alfinaya. (2017). Determinan Leverage serta Implikasinya Terhadap Harga Saham (Studi Kasus pada PT. Kalbe Farma Tbk. Tahun 2006-2015). Universitas Pamulang.

Oktaviana, Diana. (2018). Pengaruh Debt to Equity Ratio (DER) dan Return On Equity (ROE) Terhadap Nilai Perusahaan (PBV) (Studi Kasus 6 Perusahaan Properti/Real Estate Tbk). Universitas Pamulang.

Pantow, Mawar S., Murni, S., \& Trang, I. (2015). Analisis Pertumbuhan Penjualan, Ukuran Perusahaan, Return On Asset, dan Struktur Modal Terhadap Nilai Perusahaan yang Tercatat di Indeks LQ45. Jurnal EMBA Universitas Sam Ratulangi, 3(1).

Sudaryo et al. (2020). Pengaruh Sales Growth (SG), Current Ratio (CR), Debt to Equity Ratio (DER), Total Asset Turn Over (TATO), Return On Asset (ROA) Terhadap Price to Book Value (PBV) (Studi pada PT. Indofarma Tbk. yang Terdaftar di BEI Periode 2012-2019). STIE Indonesia Membangun, EKONAM: Jurnal Ekonomi, 2(1).

Sunardi, N. (2017). Pengaruh Profitabilitas, Firm Size, Risiko Bisnis, Asset Growth, Leverage, Kebijakan Dividen Terhadap Institutional Ownership (Perusahaan Property \& Real Estate yang terdaftar di Bursa Efek Indonesia Tahun 20112014). INOVASI, 2(2).

Sutrisno, Wahyu Adi, \& Yulianeu. (2017). Pengaruh CR, DER dan TATO Terhadap PBV dengan ROA sebagai Variabel Intervening (Studi pada Perusahaan Property \& Real Estate yang Terdaftar pada BEI Tahun 2010-2014). Universitas Pandanaran Semarang.

Utami, Rahmawati B., \& Prasetiono. (2016). Analisis Pengaruh TATO, WCTO, dan DER Terhadap Nilai Perusahaan dengan ROA sebagai Variabel Intervening (Studi pada Perusahaan Manufaktur yang Terdaftar di Bursa Efek Indonesia Periode Tahun 2009-2013). Diponegoro Journal of Management, 5(2).

Kadim, A., Sunardi, N., \& Husain, T. (2020). The modeling firm's value based on financial ratios, intellectual capital and dividend policy. Accounting, 6(5), 859-870.

Kadim, A., \& Sunardi, N. (2019). Pengaruh Profitabilitas, Ukuran Perusahaan Terhadap Leverage Implikasi Terhadap Nilai Perusahaan Cosmetics and Household yang terdaftar di Bursa Efek Indonesia. Jurnal SEKURITAS (Saham, Ekonomi, Keuangan dan Investasi), 3(1), 22-32. 